\title{
Aptamers Switch On Fluorescence of Triphenylmethane Dyes
}

Jeremy R. Babendure, Stephen R. Adams, and Roger Y. Tsien

\section{Supplemental Material}

Patent Blue dyes PBV and PBVF were purified by HPLC using a $\mathrm{C}_{18}$-reverse-phase column with a linear gradient of $10-90 \%$ acetonitrile in water with $0.1 \%$ TFA. The major peak was collected, evaporated and identified by ES-MS.

\section{Synthesis of IMG:}

\section{5,5'-Bis(N-methylindolinyl)phenylmethane:}

A solution of $\mathrm{N}$ - methyl indoline ${ }^{1}(133 \mathrm{mg}, 1 \mathrm{mmol})$ and benzaldehyde $(51 \mu \mathrm{L}, 0.5 \mathrm{mmol})$ in dry $\mathrm{CH}_{2} \mathrm{Cl}_{2}(1 \mathrm{~mL})$ under $\mathrm{N}_{2}$ at $0{ }^{\circ} \mathrm{C}$ was treated with freshly-sublimed $\mathrm{AlCl}_{3}(67 \mathrm{mg}$, $0.5 \mathrm{mmol}$ ). The reaction mixture turned green slowly and was allowed to warm up to room temperature and left overnight. The reaction mixture was quenched with $1 \mathrm{M} \mathrm{KOH}$ $(10 \mathrm{~mL})$ and extracted with $\mathrm{CH}_{2} \mathrm{Cl}_{2}(3 \times 15 \mathrm{~mL})$. The extracts were dried over $\mathrm{Na}_{2} \mathrm{SO}_{4}$ and evaporated to an oil that was purified by $\mathrm{SiO}_{2}$ chromatography by elution with ethyl acetate-hexanes $(1: 9 \mathrm{v} / \mathrm{v})$ to give the product as a colorless oil. Yield, $90.8 \mathrm{mg}(51 \%)$. NMR ( $\left.{ }^{1} \mathrm{H}, \mathrm{CDCl}_{3}\right) 2.75$ (s, 6H, N-Me), 2.89 (t, 4H, H-2, 2' J=8 Hz), 3.31 (t, 4H, H-3, 3' $\mathrm{J}=8 \mathrm{~Hz}), 5.35$ (s, 1H, H-1, 1'), 6.45 (d, 2H, H-7, 7' J=7.8 Hz), 6.82 (broad d, 4H, H$4,4^{\prime}, 6,6$ ' J=9.4Hz), 7.1-7.3 (m, 5H, phenyl). ${ }^{(1)}$

\section{IMG (bis(N-methylindolinyl) Malachite Green:}

5,5'-Bis(N-methylindolinyl)phenylmethane $(45 \mathrm{mg}, 0.13 \mathrm{mmol}$ ) dissolved in $2 \mathrm{~mL} \mathrm{95 \%}$ EtOH was treated with chloranil $(38 \mathrm{mg}, 0.15 \mathrm{mmol})$ and gently heated until reaction was complete as judged by TLC $\left(\mathrm{SiO}_{2}, 20 \% \mathrm{MeOH}-\mathrm{CHCl}_{3}\right)$, in which the product is a greencolored spot with $\mathrm{R}_{\mathrm{f}} \sim 0.20$ ). The reaction mixture was evaporated, dissolved in $\mathrm{MeOH}$ (1 $\mathrm{mL})$ and $1 \mathrm{M}-\mathrm{HCl}(0.5 \mathrm{~mL})$, heated briefly and re-evaporated. The product was purified by $\mathrm{SiO}_{2}$ chromatography (eluted with $20 \% \mathrm{MeOH}-\mathrm{CHCl}_{3}$ ) to give a dark green solid. Yield >95\%. NMR ( $\left.{ }^{1} \mathrm{H}-\mathrm{NMR}, \mathrm{CDCl}_{3}\right) 3.20$ (s, 6H, N-Me), 3.73 (t, 4H, H-2,2'), 3.94 (t, 2H, H-3,3'), 6.67 (d, 2H, H-7,7'), 7.0 (broad d, 2H, H-6,6'), 7.1-7.6 (broad m, 6H, H-7,7', phenyl).

\section{Synthesis of MG and SRB RNA Aptamers:}

Malachite Green aptamer RNA (5' GGAUCCCGA CUGGCGAGAG CCAGGUAACG AAUGGAUCC ) and Sulforhodamine B aptamer RNA (5' GGAACCUCGCUUCGGCGAUGAUGGAGAGGCGCAAGGUUAACCGCCUCAGG UUCC) were produced as follows: 200 pmol DNA anti-sense to MG aptamer (GGATCCATTCGTTACCTGGCTCTCGCC AGTCGGGATCCTATAGTGAGTCGTATTAAGCT) or SRB aptamer (GGAACCTGAGGCGGTTAACCTTGCGCCTCTCCATCATCGCCGAAGCGAGGTT CCTATAGTGAGTCGTATTAAGCT) were annealed with 200 pmol T7 sense DNA (AGCTTAATACGACTCACTATAGGA) in $200 \mu \mathrm{L}$ annealing buffer $(50 \mathrm{mM} \mathrm{NaCl}$, 
100mM HEPES pH7.4). $30 \mu \mathrm{L}$ (60pmol) of annealed DNA, $10 \mu \mathrm{L}$ (400units) of Invitrogen RnaseOut and $25 \mu \mathrm{L}$ (500units) of Promega RNA polymerase was added to a final volume of $500 \mu \mathrm{L}$ in transcription reaction buffer $(20 \mathrm{mM} \mathrm{NaCl}, 12 \mathrm{mM} \mathrm{MgCh}$, $4 \mathrm{mM}$ spermidine, $20 \mathrm{mM}$ DTT, $2 \mathrm{mM}$ NTPs and $80 \mathrm{mM}$ Tris- $\mathrm{HCl} \mathrm{pH}$ 7.9). Transcription was allowed to go overnight at $37 \mathrm{C}$. The RNA product was precipitated with ammonium acetate, re-dissolved in formamide gel running buffer and purifed by electrophoresis on a $10 \%$ denaturing acrylamide gel. RNA aptamers were excised from gel and soaked in dissociation buffer (0.1mM EDTA, $0.1 \%$ SDS, $500 \mathrm{mM} \mathrm{NaCl}, 10 \mathrm{mM}$ Tris pH7.4). RNA was next ethanol precipitated and dissolved in DEPC treated $\mathrm{H}_{2} \mathrm{O}$. Samples were stored at $-20 \mathrm{C}$ until further use.

\section{Determi nation of fluorescence quantum yields and affinities:}

All quantum yields were determined by comparing the integral of the corrected emission spectra with the corresponding integral obtained from a solution of Cresyl Violet in methanol, whose absorbance was adjusted to match that of the sample of interest at the excitation wavelength. The absolute quantum yield of Cresyl Violet was taken to be $0.545^{(2)}$. The refractive index correction was negligible because methanol and aqueous buffers differ in refractive index by $<0.01$.

The qua ntum yields of the free dyes $\left(Q_{D}\right)$ were determined in $1 \mathrm{X}$ selection buffer. Dissociation constants $K$ and quantum yields for their complexes with aptamers $\left(Q_{R D}\right)$ were determined by measuring the apparent quantum yields $\left(Q_{a p p}\right)$ as a function of increasing total added RNA $\left(R_{T}\right)$ at a fixed concentration of total dye $\left(D_{T}\right)$, and leastsquares fitting to the following model for 1:1 complexation. Let $[R]$ and $[D]$ be the concentrations of free RNA and free dye respectively. Let $K$ be the dissociation constant for their complex. Then the concentration $[R D]$ of the RNA:dye complex is given by:

$[R D]=\frac{[R][D]}{K}=\frac{\left(R_{T}-[R D]\right)\left(D_{T}-[R D]\right)}{K}$

The solution of this quadratic equation for [RD] is

$$
[R D]=\frac{D_{T}+R_{T}+K-\sqrt{\left(D_{T}+R_{T}+K\right)^{2}-4 D_{T} R_{T}}}{2}
$$

The apparent quantum yield $Q_{a p p}$ for a mixture of free dye (whose quantum yield is $Q_{D}$ ) and aptamer-dye complex (whose quantum yield is $Q_{R D}$ ) is

$$
\begin{aligned}
& Q_{\text {app }}=\frac{Q_{D}[D]+Q_{R D}[R D]}{D_{T}}=Q_{D}+\frac{\left(Q_{R D}-Q_{D}\right)[R D]}{D_{T}} \\
& =Q_{D}+\left(Q_{R D}-Q_{D}\right)\left[\frac{D_{T}+R_{T}+K-\sqrt{\left(D_{T}+R_{T}+K\right)^{2}-4 D_{T} R_{T}}}{2 D_{T}}\right]
\end{aligned}
$$

The smooth curves in Fig. 1c-1f are the best fits of the measured $R_{T}$ and $Q_{a p p}$ values (solid circles) to the above equation, with $K$ and $Q_{R D}$ as the fitted parameters listed in the text and in Table 1 . The measured $Q_{D}$ and the deduced $Q_{R D}$ are also respectively shown as the lower and upper horizontal asymptotes in Figs. 1c-1f. Total dye concentrations $\left(D_{T}\right)$ were $320 \mathrm{nM}$ for MG (Fig. 1a and 1c), $260 \mathrm{nM}$ for IMG (Fig. 1a and 1d), 1.45 $\mu \mathrm{M}$ for PBVF (Fig. 1b and 1e), and $1.0 \mu \mathrm{M}$ for PBV (Fig. 1b and 1f). For the spectra of aptamer- 
dye complexes in Fig. 1a, the concentrations of MG aptamer were $4 \mu \mathrm{M}$ and $10 \mu \mathrm{M}$ for MG and IMG respectively. In Fig. 1b, the SRB aptamer was $60 \mu \mathrm{M}$ for both complexes.

\section{Multimer Data:}

To determine if multiplying aptamer sequences in tandem could increase fluorescence intensity levels, we cloned, amplified and transcribed MG aptamer sequences as monomers, dimers, trimers, tetramers and pentamers and compared fluorescence intensity levels at equimolar concentrations of RNA $(10 \mu \mathrm{M})$. As shown in Fig. 2, increasing the number of concatenated MG aptamers resulted in increased levels of fluorescence, particularly addition of the $3^{\text {rd }}$ and $5^{\text {th }}$ units, whereas the $2^{\text {nd }}$ and $4^{\text {th }}$ units gave lesser increments, suggesting that they may function only as spacers. Currently only 6 bases separate each aptamer unit, so increasing the spacer length might permit each aptamer to fold and bind MG independently, thus increasing fluorescence levels. Nevertheless, these results suggest that multiple MGs bound to concatenated aptamers do not quench each other as multiple fluorophores often do when conjugated to a single antibody. Therefore increased brightness is attainable if higher molecular weight is tolerable.

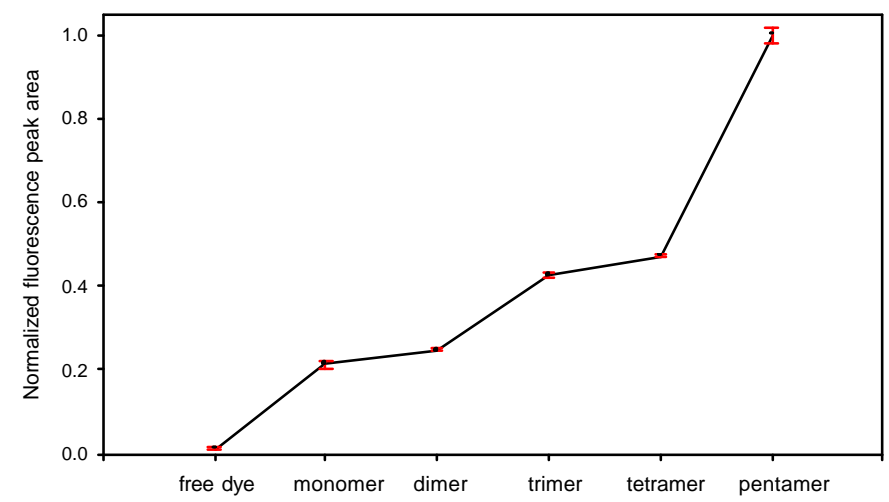

Reference List

(1) Gribble, G. W.; Nutaitis, C. F. Synthesis 1987, 709-711.

(2) Magde, D.; Brannon, J. H.; Cremers, T. L.; Olmsted, J. J.Phys.Chem. 1979, 83, 696-699. 